\title{
Review of Infectious Disease Ecology: Effects of Ecosystems on Disease and of Disease on Ecosystems by Richard S. Ostfeld, Felicia Keesing, and Valerie T. Eviner Jean-François Guégan ${ }^{1,2}$
}

\author{
Address: ${ }^{1}$ Genetics and Evolution of Infectious Diseases, IRD, Montpellier, France and ${ }^{2}$ French Center on Globalization and Infectious Diseases, \\ French School of Public Health, Montpellier, France \\ Email: Jean-François Guégan - guegan@mpl.ird.fr \\ Published: 29 August 2008 \\ Parasites \& Vectors 2008, I:28 doi:10.1 186/1756-3305-I-28 \\ This article is available from: http://www.parasitesandvectors.com/content/I/I/28 \\ (c) 2008 Guégan; licensee BioMed Central Ltd. \\ This is an Open Access article distributed under the terms of the Creative Commons Attribution License (http://creativecommons.org/licenses/by/2.0), \\ which permits unrestricted use, distribution, and reproduction in any medium, provided the original work is properly cited. \\ Received: 30 July 2008 \\ Accepted: 29 August 2008
}

\section{Book details}

Ostfeld RS, Keesing F, Eviner VT: Infectious Disease Ecology. Effects of Ecosystems on Disease and of Disease on Ecosystems Princeton University Press; 2008. 506 pages. ISBN 978-0691-12484-1 (hardcover); ISBN 978-0-691-12485-8 (pbk.)

\section{Review}

We all as humans stay at the parasites' place which in turn reside in us! Nous demeurons chez des microbes qui nous habitent!

Are we totally wrong in thinking that we are, as humans, like all other living organisms on Earth, (just) hosts and resources for parasites! On the contrary, would we be just staying at a parasites' home, since that our point of view on parasites and pathogens is totally flawed by an anthropogenic, too medically-oriented perspective? At a time where we are demonstrating that the human genome is not a single-formed entity but it is made for a substantial part of past genetic interactions between environmentally-resident pathogens and our species, the book coedited by Richard S. Ostfeld, Felicia Keesing, and Valerie $\mathrm{T}$. Eviner comes at just the right moment in offering some refreshing ideas and opening new research avenues on the exact role played by parasites in ecosystems, and vice versa. The book is composed of four parts - Part I, Effects of Ecosystems on Disease; Part II, Effects of Disease on Ecosystems; Part III, Management and Applications; Part IV, Concluding Comments: Frontiers in the Ecology of Infectious Diseases. It puts together 22 different chapters, most having being written by the more talented and influential research individuals in the fields of ecology of infectious diseases and disease management. People more interested in vectors 


\section{Competing interests}

The author declares that they have no competing interests.

Publish with Bio Med Central and every scientist can read your work free of charge

"BioMed Central will be the most significant development for disseminating the results of biomedical research in our lifetime. " Sir Paul Nurse, Cancer Research UK

Your research papers will be:

- available free of charge to the entire biomedical community

- peer reviewed and published immediately upon acceptance

- cited in PubMed and archived on PubMed Central

- yours - you keep the copyright 